\title{
Pendidikan Karakter Analisis Pemikiran Ibnu Miskawaih
}

\author{
Fitriani Rahayu \\ UIN Sunan Kalijaga Yogyakarta, Kabupaten Sleman, Indonesia \\ E-mail : fi3ani.rhy@gmail.com
}

\begin{abstract}
ABSTRAK
Pendidikan karakter menjadi hal yang sangat penting untuk ditanamkan pada anak usia sekolah mengingat banyaknya krisis moral yang terjadi dikalangan remaja belakangan ini. Selain itu, Indonesia juga kekurangan tokoh-tokoh yang dapat dijadikan sebagai teladan. Hal ini disebabkan para figure pablik sekarang banyak yang melakukan kriminalitas seperti korupsi, kolusi, prostitusi, dan lain sebagainya. Ibnu Miskawaih adalah salah satu tokoh filsafat islam yang menyentuh konsep tentang pendidikan karakter dalam bukunya tahzib al-akhlak wa tahir al-a'raf. Dengan menggunakan studi literature, tulisan ini berusaha untuk memaparkan konsep pendidikan karakter yang ditawarkan oleh Ibnu Maskawaih yang dikenal dengan jalan tengah atau al-wasath. Ia mengungkapkan bahwa karakter manusia terbangun dari empat landasan yaitu menahan diri, keberanian, kebijaksanaan, dan keadilan. Nilai-nilai karakter yang dikembangkan oleh Ibnu Maskawaih ini bisa dijadikan sebagai salah satu rujukan pelaksanaan pendidikan di Indonesia. Nilai-nilai atau karakter yang diharapkan adalah terbentuknya kepribadian yang dilandasi norma-norma agama, budaya dan etika bangsa Indonesia. Sehingga, pemikiran ibnu Miskawaih ini sangat cocok digunakan di era krisis moralitas seperti sekarang ini.
\end{abstract}

Kata Kunci : Pendidikan Karakter, Ibnu Miskawaih, Akhlak, Konsep Manusia

\begin{abstract}
Character education is a important thing to be instilled in school-age children given the many moral crises that have occurred among teenagers lately. In addition to, Indonesia lacks figures who can be used as a role model. That done because many public figures commited the crimes such as corruption, collusion, prostitution, and so on. Ibnu Miskawaih is one of the Islamic philosophers who touches on the concept of character education in his book tahzib al-akhlak wa tahir al-a'raf. By literature studies, this paper attempts to describe the concept of character education offered by Ibnu Maskawaih, namely The Golden (The Doctrin of The Mean). He stated that human character is built from four foundations, namely restraint, courage, wisdom, and justice. The character values developed by Ibnu Maskawaih can be used as a reference for the implementation of education in Indonesia. The expected values or characters are the formation of personality based on the norms of religion, culture and ethics of the Indonesian nation. So, the thought of Ibn Miskawaih is so suitable for using in morality crisis era.
\end{abstract}

Key Word : Character Education, Ibnu Miskawaih, Morals, Human Concept

Article history:

Received: 28-11-2018

Revised: 10-1-2019

Accepted: 14-1-2019 


\section{PENDAHULUAN}

Pendidikan karakter menjadi bahasan yang sangat strategis dalam konteks pendidikan di Indonesia sekarang ini. Hal ini berkaitan dengan krisis moral yang terjadi belakangan ini. Hampir semua kasus yang terjadi disebabkan oleh kegagalan dari lembaga-lembaga pendidikan dalam menerapkan pendidikan karakter. Kasus-kasus yang berskala nasional ini banyak disebabkan oleh kurangnya proses penanaman pendidikan akhlak pada anak usia sekolah. Dalam konteks kekinian, nilai-nilai etika pendidikan yang baik sangat dibutuhkan untuk membentuk karakter generasi muda yang ditanamkam melalui jalur pendidikan. Hal ini disebabkan bahwa semakin modern manusia mengalami krisis moral dan etika yang menjadi prinsipprinsip hidup bermasyarakat.

Krisis yang banyak terjadi di Indonesia salah satunya adalah krisis tokoh-tokoh yang bisa diteladani, banyak kasus-kasus kriminal yang dilakukan oleh orang yang menjadi figur di masyarakat, seperti kasus korupsi kolusi dan sebagainya. Begitu juga di kalangan pelajar yang terjadi adalah perilaku-perilaku yang bertentangan dengan moral atau akhlak Islam seperti seks bebas, narkoba, tawuran, dan lain sebagainya yang berdampak bagi perkembangan jiwa anak didik (Unayah, 2015: 131). Belum lagi pengaruh budaya asing yang dengan mudah diakses oleh anakanak melalui situs-situs negatif yang berada di dunia maya (internet). Oleh karena itu, pembentukan dan pembinaan etika yang baik sejak dini dalam konteks pendidikan perlu dilakukan.

Dalam psikologi islam, desain karakter islam diturunkan dari ajaran akhlak yang merupakan bagian khusus dari komponen Islam (Mujib, 2012). Sehingga dalam pengembangan pendidikan karakter tidak bisa dilepaskan dari pemberian ranah akhlak dalam pendidikan. Dalam perspektif muatan pendidikan karakter harus terwujudkan dalam setiap kontens kurikulum pendidikan dari berbagai disiplin ilmu yang 
diajarkan di sekolah maupun di madrasah. Oleh karena itu perlu dilakukan kajian ulang terhadap konsep-konsep etika Islam yang menjadi pilar pengembangan pendidikan karekter di tanah air, dengan cara mengkaji konsep etika yang digagas oleh para ulama Islam. Salah satu diantaranya adalah konsep etika menurut Ibnu Maskawaih. Konsep ini bisa dijadikan rujukan untuk menggagas konsep ideal dan praksis tentang pendidikan karakter yang bersumber dari pemikiran para ulama atau filosof muslim.

Untuk itu dalam mengkaji tentang pemikiran Ibnu Maskawaih, penulis menggunakan stadi literature atau kepustakaan dari berbagai refrensi dan data yang ada. Kemudian data tersebut dikemas sebagai bahan informasi yang dapat memberikan gambaran mengenai pendidikan karakter menurut Ibnu Maskawaih dan relevansinya di era modern.

\section{PERMASAlahan}

\section{Biografi}

Nama lengkap Ibnu Maskawaih adalah Abu Ali Al-Khozin Ahmad Ibnu Muhammad bin Ya'qub bin Miskawaih. Nama Miskawaih diambil dari nama kakeknya yang semula beragama Majusi (Persi) yang kemudian masuk islam. Gelarnya adalah Abu Ali, yang didapatkan dari nama sahabat Ali bin Abi Thalib. Bagi kaum Syi'ah Ali bin Abi Thalib dipandang sebagai yang berhak menggantikan Nabi Muhammad sebagai pemimpin umat Islam sepeninggalnya. Sehingga dari gelar ini, tidak salah apabila orang mengatakan Miskawaih adalah penganut aliran Syi'ah (Rahmaniyah,2010: 105).

Ibnu Miskawaih yang terkenal dengan julukan al-Khazain, dan juga digelari sebagai "guru ketiga" setelah Aritoteles dan al-Farabi. Ia lahir di Rayy (yang sekarang Teheran, Iran) tahun 320 H / 932 $\mathrm{M}$ dan wafat pada tahun $421 \mathrm{H} /$ 1030 M (Miskawaih, 1994: 29). Ibnu Miskawaikh merupakan seorang otodidak yang sukses dalam menggeluti berbagai disiplin 
ilmu sehingga menjadikannya sebagai "Bapak Filsafat etika Muslim" dan "Bapak Psikologi Pendidikan Muslim”. Selain itu, ia juga seorang sejarahwan, sastrawan, dan pendidik (Mahmud, 2011: 277).

Jika melihat dari tahun lahir dan wafatnya, Miskawaih hidup pada masa pemerintahan Bani 'Abbas di bawah pengaruh Bani Buwaih yang beraliran Syi'ah dan berasal dari keturunan Persi. Bani Buwaih mulai berpengaruh sejak Khalifah al-Mustakfi dari Bani 'Abbas mengangkat Ahmad bin Buwaih sebagai perdana menteri (amir al-Umara') dengan gelar mu'izz ad-Daulah pada $945 \mathrm{M}$. Pada masa inilah Miskawaih memperoleh kepercayaan untuk menjadi bendaharawan. Pada masa ini jugalah Miskawaih dikenal sebagai seorang filsuf, tabib, ilmuan, dan pujangga. Tetapi, satu hal yang tidak menyenangkan di hati Miskawaih yaitu kemerosotan moral yang melanda masyarakat. Oleh karena itulah Miskawaih lalu tertarik untuk menitikberatkan perhatiaanya dalam bidang etika Islam (Basyir, 1983: 2).

Riwayat pendidikan Miskawaih tidak diketahui dengan jelas disebabkan ia tidak menulis otobiografinya sendiri. selain itu para penulis riwayat hidupnya pun tidak memberikan gambaran yang jelas mengenai hal ini. Namun, dapat diduga bahwa Miskawaih tidak berbeda dari kebiasaan anak pada masanya dalam menuntut ilmu. Ahmad Amin memberikan gambaran pendidikan anak pada zaman 'Abbasiyah bahwa pada umumnya anak-anak berawal dari belajar membaca, menulis, mempelajari al-Quran, dan tata cara bahasa Arab di surau-surau, dan dengan cara mendatangkan guru privat dalam keluarga. Kemudian setelah ilmu-ilmu dasar terselesaikan, anak kemudian diberikan ilmu fikih, sejarah, dan matematika (Basyir, 1983: 3).

Diduga Miskawaih pun menjalani pendidikan semacam itu pada masa mudanya. Meskipun menurut dugaan lain juga mengatakan bahwa Miskawaih tidak mengikuti pelajaran privat, 
karena ekonomi keluarganya yang kurang mampu untuk mendatangkan guru, terutama untuk pelajaran lanjutan yang biayanya mahal. Perkembangan ilmu Miskawaih selanjutnya diperoleh dengan jalan banyak membaca buku-buku, terutama di saat-saat memperoleh kepercayaan menguasai perpustakaan Ibn al'Amid (Basyir, 1983: 3).

Ibnu Miskawaih dikenal sebagai seorang pemikir yang produktif. Ia telah menghasilkan banyak karya tulis, tetapi hanya sebagian kecil yang sekarang masih ada. Jumlah buku dan artikel yang berhasil ditulis oleh Ibnu Miskawaih ada 41 buah (Rahmaniyah, 2010: 111). Menurut Ahmad Amin, semua karya Ibnu Miskawaih tidak luput dari kepentingan filsafat akhlak. Sehubungan dengan hal itu, tidak heran jika Ibnu Miskawaih dikenal sebagai moralis. Abu Mansur alTslabi menerangkan bahwa Ibnu Miskawaih adalah pribadi mulia yang penuh dengan keutamaan, halus budi, ahli sastra, ahli balaghah, ulet, dan sebagai seorang penyair (Gunawan, 2014: 304).
Tulisan-tulisan dan karya-karya Ibnu Miskawaih banyak dipengaruhi oleh filsafat Yunani, peradaban Persia, ajaran syariat islam, dan pengalaman pribadi (Rahmaniyah, 2010: 110).

Namun, bila diperhatikan daftar tulisan Ibnu Maskawaih, tidak ditemukan satu pun yang membahas secara khusus tentang pendidikan. Akan tetapi, ada beberapa buku yang pembahasannya dinilai banyak berkaitan dengan pendidikan, seperti tentang kejiawaan, akal, dan etika. Salah satu bukunya yang banyak membahas teori dan konsep pendidikan ialah Tahzib alAkhlaq wa Tathir al-A'raq Pendidikan Budi dan Pembersihan Akhlak- (Mahmud, 2011: 278).

Dalam kitab yang terdiri dari tujuh bagian ini, secara umum ia membicarakan tentang bagaimana seseorang dapat mencapai kebahagiaan tertinggi melalui moral yang sehat. Dengan kata lain buku ini menggambarkan bagaimana berbagai bagian jiwa diharmonikan untuk mencapai kebahagiaan. Inilah yang menjadi peran para 
filsuf moral atau etika untuk memberikan resep bagi kesehatan yang berpijak pada kombinasi pengembangan intelektual dan praktik keseharian (Murtiningsih, 2014: 264).

Sebagai seorang filsuf akhlak, pemikiran Ibnu Miskawaih dalam pendidikan tidak bisa lepas dari konsepnya tentang manusia dan akhlak. Maka berbicara tentang pemikiran pendidikan Ibnu Miskawaih lebih tepat jika kita mengkaji terlebih dahulu tentang dasar pemikiran pendidikan beliau, yang terkait dengan tingkatan daya dan akhlak.

\section{Konsep Yang Melandasi Pemikiran Pendidikan Ibnu Miskawaih}

Dari berbagai karyanya, Ibnu Miskawaih banyak membahas persoalan-persoalan filsafat.

Pemikirannya tentang pendidikan bertumpu pada tema manusia, jiwa, dan akhlak (Mahmud, 2011: 278-279) berikut pemaparannya :

1. Konsep Manusia

Ketika seseorang memahami kata al-insan berasal dari kata al-nasyan, seakan- akan mereka memberikan justifikasi bahwa, ketika manusia tidak menepati janji atau mengerjakan hal-hal yang bersifat negative dengan alasan lupa merupakan kesalahan yang wajar-wajar saja. Memang manusia selalu luput dari kesalahan, sebagaimana yang telah disabdakan oleh Nabi Muhammad saw : "Setiap keturunan Adam pasti berbuat kesalahan dan sebaik-baik kesalahan adalah pertaubatan". Bahkan dalam pepatah diaktakan bahwa "manusia adalah tempat salah dan lupa". Namun kata insan menurut Ibn Madzur dapat diambil dari tiga akar kata yaitu; Anas, Annisa, Nasia.

- Annas yang artinya :

- 'abshara : melihat, bernalar, dan berpikir. Dengan demikian manusia dapat mengambil pelajaran dari apa yang dilihatnya.

- 'alima: mengetahui, berilmu. Dengan ilmu manusia dapat 
membedakan antara yang baik dan yang salah.

- istadzana: meminta izin, makhluk yang beradab. Dengan ini manusia cenderung untuk meminta izin melakukan sesuatu yang bukan kewenangannya. Dari kata ini, insan dimaknai sebagai makhluk yang mempunyai daya nalar, berilmu, dan beradab.

- Anisa : artinya alifaibu wa sakana qalbuhu bihi: jinak, ramah, lawan kata tawakhasya: buas. Dari kata ini, dapat disimpulkan manusia adalah makhluk yang bersahabat dan ramah dalam pergaulan.

- Nasia artinya dliddu tadzakkara, yaitu lupa.

Dengan demikian dapat kita simpulkan, pengertian alinsan adalah makhluk yang dapat maju dan berkembang dengan mengunakan daya pikir dan nalarnya. Ia berilmu, yang dengan ilmu dapat membedakan antara yang benar dan yang salah. Ia beradab, tidak suka merampas dan mengambil hak orang lain tanpa izin. Ia ramah dalam pergaulan, bersahabat, serta dapat menyesuaikan diri dengan lingkungannya. Ia kadang lupa dan tidak selalu ada dalam kebenaran.

Menurut pandangannya, manusia adalah makhluk yang memiliki keistimewaan karena dalam kenyataannya manusia memiliki daya pikir. Berdasarkan daya pikir tersebut, manusia dapat membedakan antara yang benar dan yang salah, serta yang baik dan yang buruk. Selain itu, Ibnu Miskawaih berpendapat bahwa untuk mewujudkan kebaikan, manusia harus membina kerjasama. Usaha untuk mewujudkan kebaikan merupakan indikator dari tingkat kesempurnaan dan tujuan dari penciptaan manusia itu sendiri.

2. Konsep Jiwa

Ibnu Miskawaih menjabarkan bahwa dalam diri manusia selain tedapat tubuh, 
juga terdapat sesuatu yang bukan tubuh, yang disebut dengan jiwa. Sebagai argument untuk menjelaskan adanya jiwa, Ibnu Miskawaih mengemukakan kenyataan tentang penerimaan atau rekaman kesadaran kita terhadap berbagai bentuk yang berasal dari benda-benda yang bersifat jasmani atau bersifat empiris. Bila yang merekam atau menerima itu bersifat jasmani, pastilah jasmani hanya bisa menerima sesuatu bentuk baru yang menggantikan bentuk yang lama. Benda jasmani hanya dapat menerima satu bentuk dalam satu saat, dan hanya bisa menerima bentuk yang berbeda pada yang waktu lain (Rahmaniyah, 2010: 119).

Ibnu

Miskawaih

menonjolkan kelebihan jiwa manusia atas jiwa binatang dengan adanya kekuatan berfikir yang menjadi sumber pertimbangan tingkah laku, yang selalu mengarah kepada kebaikan. Lebih jauh menurutnya, jiwa manusia mempunyai tiga kekuatan yang bertingkat-tingkat.

- Daya nafsu (al-Nafs alBahimiyyah) yang buruk. Jiwa ini menjadi dasar syahwat, usaha mencari makan, kerinduan untuk menikmati makanan, minuman, perkawinan, serta berbagai kenikmatan individu lainnya. Pusat daya jiwa ini ada di dalam hati.

- Daya Berani (al-Nafs alSabua'iyyah) yang sedang. Jiwa ini menjadi dasar kemarahan, tantangan, dan keberanian atas hal yang menakutkan. Pusatnya di hati.

- Daya berfikir (al-Nafs alNatiqah) yang baik. Jiwa ini merupakan jiwa yang menjadi dasar berfikir, membedakan, dan menalar hakikat segala sesuatu. Pusatnya pada otak.

Manusia

dikatakan menjadi manusia yang sebenarnya jika memiliki jiwa yang cerdas. Dengan jiwa yang cerdas itu, manusia tingkat 
derajatnya dan dengan itu pula manusia dapat dibedakan dengan binatang. Berkenaan dengan hal ini, Ibnu Miskawaih mengatakan bahwa jiwa yang rendah atau buruk mempunyai sifat ujub, sombong, pengolokolok, penipu, dan hina. Sedangkan jiwa yang cerdas mempunyai sifat adil, harga diri, berani, pemurah, dan cinta (Rahmaniyah, 2010: 124).

3. Konsep Akhlak

Menurut Ibnu Miskawaih, pada dasarnya karakter dari sifat manusia yang harus dibangun dengan menggunakan teori The Golden Mean atau yang lebih dikenal dengan jalan tengah (al-wasath). Jalan tengah yang dimaksud oleh Ibnu Miskawaikh adalah dengan adanya sikap seimbang, moderat, harmoni, utama, mulia (Hamim, 2014: 26). Menurut Ibnu Miskawaikh ada 4 karakter, yang menjadi pondasi bagi pengembangan karakter mulia manusia yakni al-Iffat (menahan diri/self control), alSyaja'at (keberanian), dan al-
Hikmat (kebijaksanaan) serta alAdalat (keadilan). Keempat karakter tersebut merupakan pokok-pokok akhlak manusia. Dan sifat-sifat lain yang berupa keutamaan akhlak manusia merupakan turunan atau cabang dari empat pokok keutamaan akhlak tersebut. Sifat-sifat utama disebut sebagai al-fadlilah, berada dalam posisi tengah (al-wasath), dari dua ektrimitas karakter atau sifat manusia yang tidak baik. Dua kutub ekstrim tersebut adalah al-Tafrith (ekstrem kekurangan) dan al-Ifrath (ekstrem kelebihan). Menurut Ibnu maskawaih bahwa setiap keutamaan karakter manusia mempunyai dua ekstrem, dan yang berada ditengah adalah karakter yang terpuji (Miskawaih, 1994).

Posisi tengah yang dimaksud adalah standar atau prinsip umum yang berlaku bagi manusia. Posisi tengah yang sebenarnya adalah (al-wasath alhaqiqi) adalah satu, yang disebut al-fadîlah (keutamaan), yang 
disebut juga al-khat al-mustaqîm (garis lurus). Empat pokok keutamaan dengan ekstrem kekurangan dan ekstrem kelebihan data dipetakan dalam tabel berikut (Abidin, 2014 : 279) :
Ekstrem
Posisi
Ekstrem
Kekurang
an
Tengah
Kelebihan
(Al- (Al-Wasath)
(Al-Ifrath)

Tafrîth)

\begin{tabular}{|c|c|c|}
\hline $\begin{array}{l}\text { Kedungua } \\
\text { n (al- } \\
\text { Balah) }\end{array}$ & $\begin{array}{l}\text { Kebijaksana } \\
\text { an (al- } \\
\text { Hikmah) }\end{array}$ & $\begin{array}{l}\text { Kelancang } \\
\text { an (al- } \\
\text { safah) }\end{array}$ \\
\hline $\begin{array}{l}\text { Pengecut } \\
(\text { (al-Jubn) }\end{array}$ & $\begin{array}{l}\text { Keberanian } \\
\text { (al- } \\
\text { Syaja'ah) }\end{array}$ & $\begin{array}{l}\text { Nekat (al- } \\
\text { Tathawwu } \\
\text { r) }\end{array}$ \\
\hline $\begin{array}{l}\text { Dingin } \\
\text { Hati (al- } \\
\text { Khumud) }\end{array}$ & $\begin{array}{l}\text { Menahan } \\
\text { Diri/ } \\
\text { menjaga } \\
\text { kesucian (al- } \\
\text { Iffāt) }\end{array}$ & $\begin{array}{l}\text { Rakus/ } \\
\text { loba (al- } \\
\text { Syarah }\end{array}$ \\
\hline Teraniaya & $\begin{array}{l}\text { Keadilan (al- } \\
\text { Adalat) = } \\
\text { (kombinasi } \\
\text { dari ketiga } \\
\text { keutamaan } \\
\text { diatas } \\
\text { menghasilka } \\
\text { n keadilan) }\end{array}$ & $\begin{array}{l}\text { Berbuat } \\
\text { Aniaya }\end{array}$ \\
\hline
\end{tabular}

Namun, tidak semua

ulama setuju dengan pembagian

karakter menurut skema yang dikembangkan oleh Ibnu Maskawaih. Menurut Ahmad Amin ada sebagian keutamaan yang tidak berada di tengahtengah dua ekstrem yang tercela, misalnya keberanian tidak berada diantara sifat nekat dan pengecut, melainkan lebih dekat dengan nekat. Begitu juga dengan dermawan lebih dekat ke karakter boros dari pada kikir (Miskawaih, 1994).

Akan tetapi, terkait dengan konsep watak manusia, penulis setuju dengan pendapat Ibnu Miskawaih yang melandaskan pilihannya pada pendapat Aristoteles. Tidak ada keburukan yang melekat abadi pada diri seseorang. Semua orang hatta dengan watak buruk sekalipun dapat berubah dengan pendidikan. Pengajaran dan pendidikan yang berkelanjutan serta bimbingan yang baik yang diupayakan manusia tentulah akan memberi pengaruh, walaupun kadarnya berbeda terhadap bermacam-macam orang. Ada di antara mereka yang menerima pendidikan dengan cepat, sedang sebagian yang lain menerimanya dengan lambat untuk menuju keutamaan. 


\section{Apakah Manusia Dapat Dididik ?}

Untuk

menjawab

pertanyaan di atas, perlu dikemukakan pendapat Ibn Miskawaih tentang karakter (watak) manusia. Manusia memiliki dua macam karakter, pertama, adalah tabi'i (alami) dan kedua, karakter yang diperoleh melalui kebiasaan dan latihan (Rahmaniyah, 2010: 147). Para cendikiawan klasik berbeda pendapat tentang hal ini. Sebagian mengatakan bahwa watak itu alami dan tidak dapat diubah, sedangkan sebagian yang lain mengatakan tidak ada satupun pada watak itu yang alami, semuanya dapat berubah.

\section{Ibnu} Miskawaih berpendapat, bahwa watak itu tidak alami. Kita diciptakan atas dasar menerima watak, namun kita berubah berkat pendidikan dan pengajaran. Pendapat inilah yang menjadi pilihan Ibnu Miskawaih karena sesuai dengan realita yang sering dijumpai dalam kejadian nyata. Pendapat pertama (yang mengatakan watak itu alami dan tak dapat dididik) mengesampingkan kekuatan tamyiz (penalaran) serta akal dan menolak segala upaya serta membiarkan manusia tidak beradab, menelantarkan para remaja dan anak-anak tanpa pendidikan (Miskawaih, 1994: 148).

Kemudian Ibnu Miskawaih mengemukakan pendapat golongan Ruwwaqiyyun, Jalinus dan pendapat Aristoteles tentang watak manusia. Golongan Rawwaqiyyun berpendapat bahwa watak itu dasarnya baik, kemudian karena pengaruh pergaulan watak yang baik itu menjadi buruk. Sedangkan Galen berpendapat bahwa sebagian watak manusia pada dasarnya (alami) jahat, sebagian lagi mengatakan watak itu dasamya baik, di antara mereka ada yang mengatakan dasar watak itu tengah-tengah antara baik dan buruk. Mereka yang wataknya alami baik, mereka tidak akan berubah menjadi buruk. Sedang mereka yang 
wataknya alami buruk, mereka tidak akan berubah menjadi baik (Majidi, 1995: 35). Mereka yang wataknya berada di tengah-tengah di antara baik dan buruk dapat berubah menjadi baik jika mendapat pengaruh pendidikan yang baik dan berubah menjadi buruk jika mendapat pengaruh pendidikan yang buruk. Kemudian Ibnu Miskawaih mengutip pendapat Aristoteles yang dijadikannya pegangan (Rahmaniyah, 2010: 148).

Menurut Aristoteles orang jahat ataupun orang yang mempunyai watak buruk dapat berubah dengan pendidikan, namun tidak mutlak. Pengajaran dan pendidikan yang berkelanjutan serta bimbingan yang baik yang diupayakan manusia tentulah akan memberi pengaruh yang berbeda-beda terhadap bermacam-macam orang. Ada di antara mereka yang menerima pendidikan dengan cepat, sedang sebagian yang lain menerimanya dengan lambat untuk menuju keutamaan (Rahmaniyah, 2010: 149).

\section{Dasar Pendidikan}

Dasar

merupakan landasan bagi berdirinya sesuatu dan ia berfungsi sebagai pemberi arah terhadap tujuan yang akan dicapai (Mahmud, 2011: 148).

- Syariat sebagai dasar pendidikan. Ibnu Miskawaih tidak menjelaskan secara pasti apa yang menjadi dasar pendidikan. Akan tetapi, ia menyatakan bahwa syariat agama merupakan faktor penentu bagi lurusnya karakter manusia.

- Pengetahuan psikologi sebagai dasar pendidikan. Ibnu Miskawaih menegaskan adanya hubungan antara pendidikan dan pengetahuan tentang jiwa. Pembentukan karakter baik tersebut dapat tercapai jika kita memahami makna jiwa, mulai permintaan, tujuan, kekuatan atau daya, dan malakah-nya. Jiwa yang dibina dengan tepat akan 
menjadikan manusia tersebut mencapai kesempurnaan. Pembinaanjiwa tersebut dapat dilakukan melalui pendidikan.

\section{Konsep Pendidikan}

Ibn

Miskawaih

membangun konsep pendidikannya yang bertumpu pada pendidikan akhlak. Karena dasar pendidikan Ibn Miskawaih dalam bidang akhlak, maka konsep pendidikan yang dibangun adalah pendidikan akhlak yang meliputi:

Tujuan Pendidikan

Ibnu

Miskawaih

mengisyaratkan bahwa tujuan pendidikan adalah terbentuknya pribadi yang berakhlak mulia, yang disebut sebagai isbah alkhuluq asy-syarif, yakni pribadi yang mulia secara substansial dan esensial. Selain itu, tujuan pendidikan juga identik dengan tujuan hidup manusia. Tercapainya tujuan pendidikan merupakan langkah bagi tercapainya tujuan hidup manusia yang terakhir, yaitu kebaikan, kebahagiaan, dan kesempurnaan seperti yang diutarakan oleh Mahmud.

Fungsi Pendidikan

Menurut Ibn Miskawaih, fungsi pendidikan adalah sebagai berikut (Mahmud, 2011: 284) :

a. Menanamkan akhlak mulia. Bagi Ibn Miskawaih, pembentukan akhlak mulia merupakan tujuan pendidikan, sekaligus sebagai fungsi pendidikan. Nilai-nilai akhlak mulia yang perlu ditanamkan dan dibiasakan itu pada aspek rohani seperti jujur, tabah, sabar, dan lainlain. Juga pada aspek jasmani seperti adab berpakaian, berbicara, dan lain-lain .

b. Memanusiakan manusia. Ibn Miskawaih menyatakan bahwa tugas pendidikan adalah menundukkan manusia sesuai dengan substansinya sebagai makhluk yang termulia. Selain itu, pendidikan bertugas mengangkat 
manusia dari tingkat terendah pada tingkat tinggi.

c. Sosialisasi individu. Sejumlah individu harus bersatu untuk mencapai kebahagiaan Bersama sehingga satu sama lainnya saling menyempurnakan. Masingmasing individu menjadikan dirinya seperti satu tubuh yang saling menunjang.

d. Menanamkan rasa malu. Rasa malu yang dimaksud disini adalah rasa takut lahirnya sesuatu yang jelek dari dirinya. Ibnu Miskawaih mengatakan bahwa tanda awal perkembangan akal adalah timbulnya rasa malu karena hal itu menunjukan bahwa anak sudah menginsafi tentang keburukan (Majidi, 1995 : 42).

\section{Materi Pendidikan}

Pada materi pendidikan Ibnu Miskawaih ditujukan agar semua sisi kemanusiaan mendapatkan materi didikan yang memberi jalan bagi tercapainya tujuan pendidikan.
Materi-materi yang dimaksud diabdikan pula sebagai bentuk pengabdian kepada Allah SWT. Materi pendidikan akhlaknya yaitu : hal-hal yang wajib bagi kebutuhan tubuh manusia, dan hal-hal yang wajib bagi jiwa. Materi pendidikan akhlak yang wajib bagi kebutuhan tubuh manusia antara lain shalat, puasa dan sa'i. Selanjutnya materi pendidikan ahklak yang wajib dipelajari bagi kebutuhan jiwa dicontohkan oleh Ibnu Miskawaih dengan pembahasan akidah yang benar, mengesakan Allah dengan segala kebesaranNya serta motivasi senang kepada ilmu dan materi yang terkait dengan keperluan manusia dengan manusia dicontohkan dengan materi ilmu muammalat, perkawinan, saling menasehati, dan lain sebagainya (Hariyanto, 2016: 115).

Metode \& Alat Pendidikan

a. Metode alami. Metode alamiah itu bertolak dari pengamatan terhadap potensi-potensi insani. Mana yang muncul terlebih dahulu, 
maka pendidikan diarahkan kepada pemenuhan kebutuhan potensi yang lahir dahulu itu, kemudian kepada kebutuhan potensi berikutnya yang lahir sesuai dengan hukum alam. Potensi yang muncul pertama kali adalah gejala umum yang ada pada tingkat kehidupan hayawani dan nabati, kemudian terus-menerus lahir suatu gejala khusus yang berbeda dengan gejala potensi lainnya sampai menjadi tingkat kehidupan insani. Maka dari itu kata Miskawaih, wajib bagi kita mulai dengan kecenderungan akan makan, yang muncul pada diri kita dengan jalan memenuhi kebutuhan kecenderungan. Lalu muncul kecenderungan ghodlabiyah dan cinta kemuliaan, kita didik dengan jalan memenuhi kecenderungan itu. Kemudian terakhir lahir kecenderungan kepada ilmu pengetahuan, maka kita didik dengan jalan memenuhi kecenderungan itu. Urutan kemunculan inilah yang kami (Miskawaih) maksudkan thabi'iy (alami), karena didasarkan proses kejadian manusia, yakni pertama kali embrio lalu bayi kemudian orang dewasa. Potensipotensi ini lahir berurutan secara alamiah. Ide pokok dari thariqun thabi'iyyun dari Miskawaih adalah bahwa pelaksanaan kerja mendidik itu hendaknya didasarkan atas perkembangan lahir batin manusia. Setiap tahap perkembangan manusia mempunyai kebutuhan psycho-phisiologis dan cara mendidik hendaklah memperhatikan kebutuhan ini sesuai dengan tahap perkembangannya (Hariyanto, 2015: 117).

b. Nasihat dan tuntutan sebagai metode pendidikan. Ibn Miskawaih menyatakan, supaya anak menaati syariat dan berbuat baik, diperlukan nasihat dan tuntrunan. Dalam Al-Quran, apa yang 
dikemukakan Ibn Miskawaih banyak ditemukan, seperti dalam surat Luqman: 1 3-19. Ini menunjukkan betapa pentingnya nasihat dalam interaksi pendidik dengan subjek didik (Mahmud, 2011: 268).

c. Ancaman, hardikan, hukuman, dan pukulan sebagai metode pendidikan. Ibn Miskawaih mengindikasikan banyak sekali yang dapat dilakukan dalam mendidik, seperti tertera di atas dan dilaksanakan secara akmat sesuai dengan tuntutan yang diperlukan. Artinya, jika subjek didik tidak melaksanakan tata nilai yang telah diajarkan, mereka diberi sanksi berbagai para sehingga mereka kembali pada tatanan nilai yang ada. Akan tetapi, pemberian sanksi harus bertahap dalam pelaksanaannya, yaitu ancaman, hardikan, kemudian pukulan (bersifat jasmani), dan hukuman baik bersifat jasmani maupun rohani.

d. Sanjungan dan pujian sebagai metode pendidikan. Ibnu Miskawaih menegaskan, jika subjek didik melaksanakan syariat dan berperilaku baik, dia perlu dipuji. Selanjutnya, jika ia didapati melakukan perbuatan yang melanggar syariat dan budi pekerti mulia, anak didik terlebih dahulu, jangan langsung dicerca, apalagi di depan orang banyak.

\section{Relevansi Pemikiran Ibnu Maskawaih di Era Modern}

Sebagaimana yang dijelaskan sebelumnya ada empat karakter yang melekat pada diri manusia yaitu bijaksana, berani, mengendalikan diri dan adil. Keempat nilai/karakter tersebut menjadi bagian dengan integral dari dari karakter universal manusia, dan karakter itu juga berlaku pada manusia Indonesia, yang mayoritas beragama Islam. Bisa dianggap bahwa empat karekter tersebut merupakan pilar-pilar utama bagi 
pembentukan karakter manusia seutuhnya. Nilai-nilai universal inilah yang kemudian dikembangkan dalam pendidikan karakter yang sedang menjadi trend pendidikan dewasa ini (Abidin, 2014: 282).

Dalam prakteknya pendidikan karakter dapat didesain dengan memasukkan nilai-nilai pendidikan karakter dalam kurikulum pendidikan nasional. Pelaksanaan pendidikan karakter di Indonesia dapat disajikan secara integral dalam muatan kurikulum tahun 2013. Berarti aspek penanaman karakter harus dikembangkan pada setiap mata pelajaran yang diberikan baik di satuan pendidikan atau institusi pendidikan formal. Dalam persepektif ini nilai-nilai karakter yang dikembangkan oleh Ibnu Maskawaih bisa dijadikan sebagai salah satu rujukan pelaksanaan pendidikan di Indonesia terutama dalam konteks pelaksanaan pendidikan Islam, maupun pelaksanaan pendidikan nasional di Indonesia. Nilai-nilai atau karakter yang diharapkan adalah terbentuknya kepribadian yang dilandasi norma-norma agama, budaya dan etika bangsa Indonesia. Tugas pendidik dalam pembinaan karakter Islami sangat mulia dan berdimensi pada upaya pembersihan hati, jiwa dan ruhani peserta didik. Guru (pendidik) harus senantiasa membiasakan sifat-sifat yang mulia, bukan hanya mengembangkan aspek intelektual (kognitif) saja melainkan juga menanamkan kepribadian yang mulia sebagai sebagai figur pendidik Islam. Oleh kerena itu dalam perspektif akhlak seorang pendidik yang baik supaya mampu mentransfer pembentukan karakter yang mulia di antaranya harus mempunyai karakter-karakter antara lain berkarakter robbaniyah (pendidik dalam arti yang berorientasi pada Tuhan, memelihara sifat mulia), ikhlas, sabar, adil, zuhud, bersih jiwa dan raganya, dan yang terpenting adalah meniatkan tugasnya untuk mendekatkan diri kepada Allah SWT, rasional, tidak emosional, dan berjiwa sosial (Abidin, 2014: 213). 
Demikian juga dari aspek siswa (peserta didik), pendidikan karakter Islam harus memperhatikan ciri khusus peserta didik. Pertama, peserta didik bukanlah miniatur orang dewasa, tetapi memiliki dunianya sendiri. Kedua, peserta didik adalah manusia yang memiliki deferiansi periodesasi perkembangan dan pertumbuhan. Ketiga, peserta didik adalah manusia yang memiliki kebutuhan, yaitu kebutuhan jasmani, kasih sayang, rasa aman, harga diri, aktualisasi diri. Keempat, peserta didik adalah makhluk Allah swt yang mempunyai perbedaan bakat dan minat. Kelima peserta didik mempunyai dua potensi jasmani dan rohani, dan mempunyai potensi absolut yaitu fitrah bertuhan dan berperi kemanusiaan. Dengan memperhatikan potensi khusus yang dimiliki peserta didik diharapkan pendidikan karakter islami oleh pendidik dapat berjalan dengan baik (Abidin, 2014: 282).

Dalam persepektif praktis, pendidikan karakter Islam dapat diupayakan dengan mendisain kurikulum pendidikan dengan alternatif yang mengggunakan pilihan model pendidikan karakter. Pendidikan karakter diberikan dengan model terpisah sebagai mata pelajaran tersendiri, atau dengan model terintegrasi dalam setiap mata pelajaran, atau model yang diberikan diluar pengajaran, bahkan bisa dilakukan dengan model gabungan. Hal ini mengindikasikan bahwa modelmeodel pendidikan karakter bersifat terbuka dan fleksibel untuk diterapkan dalam dunia pendidikan.

Sebagaimana di jelaskan diatas bahwa pemikiran Ibnu Maskawaih dibangun bertumpu pada pendidikan akhlak. Tujuan pendidikan akhlak Ibnu Maskawaih berupa terbentuknya karakter (akhlak) yakni terbentuknya sikap batin yang mampu mendorong secara spontan untuk melahirkan semua perbuatan yang bernilai baik, sehingga mencapai kesempurnaan dan memperoleh kebahagiaan sejati dan sempurna. Jika seorang guru telah mampu menciptakan anak didik dalam 
taraf pencapaian kebijaksanaan yang tinggi Ibnu Maskawaih menganggap bahwa guru tersebut telah berada dalam posisi yang tinggi dan berderajat al-mu'alim almisal, alhakim, atau al-mualim alhikmat. Derajat seperti itu menurut Maskawaih sesuai dengan konsepnya tentang manusia ideal (al- Insān al-Fadîlat). Mereka yang berada dalam garis posisi tertinggi tersebut sejajar dengan posisi para Nabi, meskipun dia bukan Nabi, terutama dalam hal sifat cinta kasih yang dimilikinya.

\section{KESIMPULAN}

Dari uraian diatas dapat diperoleh kesimpulan bahwa Ibnu Miskawaih adalah seorang filsuf besar islam yang sebagian besar keilmuannya diperoleh melalui jalan membaca. Ia menyandang gelar guru ketiga setelah aristoteles dan al-farabi. Pemikiran Ibnu Miskawaih sangat dipengaruhi oleh filsafat Yunani, peradaban Pesia, ajaran syariat Islam dan pengalaman pribadi. Walaupun tidak ditemukan satupun yang mebahas secara khusus tentang pendidikan karakter, namun dalam beberapa karyanya dinilai banyak berhubungan dengan pendidikan.

Ibnu Miskawaikh dikenal dengan konsepnya jalan tengah atau the golden mean. Ada 4 karakter, yang menjadi pondasi bagi pengembangan karakter mulia manusia yakni menahan diri, keberanian, kebijaksanaan, dan keadilan. Keempat karakter ini merupakan pokok-pokok akhlak manusia. Nilai-nilai inilah yang kemudian dikembangkan dalam pendidikan karakter pendidikan zaman ini.

Menurut Ibnu Miskawaih hakikat dan fungsi dari pendidikan adalah untuk membentuk kepribadian diri manusia sehingga terbentuk manusia yang memiliki karakter terpuji. Karena pada dasarnya akhlak manusia dapat diubah melalui pendidikan dan lingkungannya. Oleh karena itu, dalam pengimplementasiaannya pendidikan karakter dapat didesain dengan memasukkan nilai-nilai pendidikan karakter dalam kurikulum pendidikan nasional. 


\section{DAFTAR PUSTAKA}

Abdul Mujib. "Konsep Pendidikan Karakter Berbasis Psikologi Islam" Seminar Nasional Psikologi Islam : Surakarta (21/04/2012), 1-10.

Abidin, Zainal. "Konsep Pendidikan Karakter Islam Menurut Ibnu Miskawaih dan Implikasinya Bagi Pendidikan Karakter Indonesia" 14, no. 02 (2014): 269-290.

Ahmad Azhar Basyir. Miskawaih: Riwayat dan Pemikiran Filsafatnya. Yogjakarta: Nur Cahaya, 1983. Busyairi Majidi. Konsep Pendidikan Para Filsof Muslim. Yogjakarta: AlAmin Press, 1997.

Hariyanto, and Febriana Anjaryati. "Character Building: Telaah Pemikiran Ibnu Miskawaih Tentang Pendidikan Karakter" 1, no. 1 (2016): 111-118.

Heri Gunawan. Pendidikan Islam: Kajian Teoritis dan Pemikiran Tokoh. Bandung: Rosdakarya, 2014.

Istigfarotul Rahmaniyah. Pendidikan Etika: Konsep Jiwa Dan Etika Perspektif Ibnu Miskawaih Dalam Konstribusinya Di Bidang Pendidikan. Malang: UIN-Malang Press, 2010.

Mahmud. Pemikiran Pendidikan Islam. Bandung: Pustaka Setia, 2011.

Miskawaih, Ibn. Menuju

Kesempurnaan Akhlak. Translated by Helmi Hidayat. Bandung: Mizan, 1994. Nur Hamim. "Pendidikan Akhlak: Komparasi Konsep Pendidikan Ibnu 38
Miskawaikh Dan Al-Ghazali" 18, no. 1 (2014): 21-40.

Unayah, Nunung, and Muslim Sabarisman. "Fenomena Kenakalan Remaja Dan Kriminalitas" 1, no. 02 (2015): 121-140.

Wahyu Murtiningsih. Para Filsuf dari Plato Sampai Ibnu Bajjah. Yogjakarta: IRCiSoD, 2014. 